\title{
レーザー光による椎間板ヘルニアの治療
}

：㕅計測を含む治㞠システムの開発

米沢卓実、“小坂理也、“小野村敏信、河野明正

阿部裕輔、井街 宏、・鎮西恒雄、・満渕邦彦、藤正臀、

\section{東京大学医学部医用電子研究施設・東京大学先端科学技術研究センター “大阪医科大学整形外科}

The system and procedure of

Percutaneous Intradiscal Laser Nucleotomy

Takumi Yonezawa, R. Kosaka*, S. Tanaka*, H. Watanabe*, T. Onomura*, Y. Abe, K. Inachi, K. Atsumi, T. Chinzei**, K. Mabuchi**. I. Fujimasa**

Inst. of Hed. Electr, and **RCAST. Univ. of Tokyo. Dept. of Orthopedics Surg. Osaka Hedical College.

Abstract

We have been studying Percutaneous Intradiscal Laser Discectomy for herniated lumbar discs. The efficasy of this method has been already comfirmed by the basic experiments using rabbit or goat lumbar discs. In this time, the safety, the easiness and the accuracy of our original PILN system is going to introduce. And the procedure of our method was charachtered with the use of a tip type pressure tranceducer.

はじめに

腰椎椎間板へルニアに対する治療法は、大別して保存 的療法と手術的治療に分けられる。近年、従来では手術 的治療を施されていた症例の一部がキモパパインによる ケモヌクレオライシスやパンチもしくはヌクレオトーム に上る経皮的鹃核摘出術が施行され、奏績を上げている。 しかしながら、ケモヌクレオライシスにおいては無視し えないアナフィラキシイショックや対麻痷の合併症が問 題となっている。また、経皮的椎間板䯣核摘出術におい ては手技上の問題点や直湰 $3 \mathrm{~mm}$ 以上のガイド針を用い ることによる合併症が题念される。以上のことから、レ 一ザーの蒸散作用を利用し、極細のレーザーファイバー を通じ、よく制御された熱蒸散を推間板䯣核部で奏行す る経皮的椎間板へルニアの治撩法を開発してきた。本法 は、安全、容易かつ短時間に治療しえる特徽のみならず、 新し々開発・改良を加えた压センサーを使用することに 上り治療に際しての適応決定、治療娞の効果判定をより 正確なものにする工夫をした。

目的

すでに、レーザー照射による組織の経時的変化や椎間 板内王の変化についての基礎的研究結果は、第 8 回、第
9 回の本学会で報告しておりその有効性を確認している。 今回は、本法の開発にあたり安全性の確保、術中操作の 容易化打よび確実な治療のために開発・改良を加えたダ ブルルーメン針、王センサーおよびレーザ一装置を紹介 する。また、人腰椎で実施することを前提に、麻醉下十 ギ腰椎を使用し行っている術手順を紹介する。 万法

本法を確立するにあたり、主に切り出したヤギ腰椎お よび麻酔下ヤギ腰椎を使用した。安全、容易かつ短時間 に有効な結果を得るために、穿刺針、ファイバーさらに レーザー装置の開発・改良を加えるとともに、レーザー 照射前後の椎間板内王を計測することにより本法の適応 と治潦効果を確実なものにすることを試みた。針、フナ イバーは、種々の組合せや加工を行い䯣核部分の蒸散お よび熱変性が有効に生じるものに改良した。評洒は高速 サーモグラフ1、サーモカップルを使用した。当初使用 していたN d：YA Gレーザー装置の安全性を高めると ともに本法での反復照射が容易かつ速やかに行えるよう にした。さらに、レーザー照射前の推間板内压の絶対值 を確認し、本法の適応決定の参考とし、レーザー照射後 の椎間板内王の減少を確認するために極細の針先型圧七 ンサーの開発をおこなつた。評洒はロードセルを設置し た荷重計により垂遖荷重をかけ、穿刺針の外筒針に一致 させ製作した区センサーの計湘記録によりおこなつた。 以上の結果によりほぼ確立し得たシステムをもとに、術 中の椎間板造影を含む術手順を確立した（F i g - 1)。 現在、麻酔下ヤギ腰椎にP I L N法を行う際に使用する 機器を下記に列挙する。

$N d-Y A G \quad$ レーザー装置

$X-r$ a $y$ 透視装置

サクションニニット

眼球防謨眼鏡

ダブルルーメン針

クオーッファイバー

王センサーと記録装置 造影刜 結果

\section{他に、術野清潔処置備品一式}

1. ダブルルーメン針：テフロンコーテイングを施した $18 \mathrm{G}$ の外套針と $23 \mathrm{G}$ の内筒針を組合せレーザー 照射時には、発生するガス、炭化物を外套側より吸 引した。外径は $1.2 \mathrm{~mm}$ であり安全に剈道核部に進入で きる。テフロンコーテイングと外の空気層により正 
常周囲組織に熱による損偪を生じない。熱分布は針 先では $200{ }^{\circ} \mathrm{C}$ 前後の発熱が記録されたが、髅核と 䄉維輪の境界部分では $40{ }^{\circ} \mathrm{C}$ 以下となり安全にレー ザー照射ができることが確認された。バーンバック による針、ファイバーの破損は、略引を加えること によりほぼ解決した。以上の結果、現在では0.3秒の レーザー照射後, 1.5-1.7秒休止を50-70回反復照射し ている(F i g-2)。

2. NdーYA Gレーザー装置の改良は操作性の改善と 照射出力の安定化を重点に改良した。出力の安定化 と正確性はコンピュータにより制御した。レーザー 照射と休止の反復モードを設置しフットスイッチの 踏み込みだけで反復照射を可能にした。プローブ部 分でのキャリブレイションにより出力の安定照射を 可能にした。

3. 平センサーについては18 Gの外套針の内径に一致 させた外径 $0.9 \mathrm{~mm}$ の針先型开センサーを開発した。 先端の汗チップは $0.5 \mathrm{~mm}$ 四方で 4 個の半導体からな るストレインゲイジで構成されており、温度ドリフ 卜・直湶性・時間安定性・ヒステリシスなどにおい て従来の王センサーに比べ絶対値の計測が可能にな つた。

4. 術手順について

1 ）麻酔下のヤギを右側卧位のたいいとする。現在、 進入は側法進入としている。

2) 刺入針を経皮的に進め、 $\mathrm{x}$ 一線透視の前後および 側面像により針先を噵核中心部に設瞋する。

3) マンドリン抜去後、正センサーを㨂入し匤計測を 行う。

4) 压センサ一抜去後、内針に設置したフナイバーを 外套針内に設置する。この際、ファイバーは内針先端よ り $1 \mathrm{~mm}$ 後方に設置することが必要である。レーザー照 射条件は前述の通りである。

5) レーザー照射後、ファイバーを内針とともに抜去 し、推間板内区を再検する。

6) 椎間板造影を㧍こなう。

7 ）外套針を除去し、終了とする。 考察と結語

安全、容易かつ短時間に腰椎推間板へルニアの治療法 をレーザーの照射により行う方法を開発してきた。現在、 王センサーの開発もほぼ終了し、従来では手術適応とな つていた症例のうち椎間板内王の上昇が症状発現の主要 因となっている症例に対し、本法の確実な適応を抗こな い得るシステムを完成した。本法は、照射出力・照射反 復回数の調節により、キモヌクレオライシスに準じる熱 変性を主体とする照射からパンチやヌクレオトームによ る檤核摘出術に準じる髄核部分の蒸散法までの適応があ る。現在、 $L_{5}-S_{1}$ への簡易な進入法として、正中進入 の安全性を確認中であり、熱電対により針表面の温度分 布を検討中である。また、照射前後の椎間板MR I 像の
変化を検討している。さらに、臨床応用を前提とし、摘 出椎間板髅核へレーザーを照射し、組織学的変性度に応 じた照射条件を設定している。

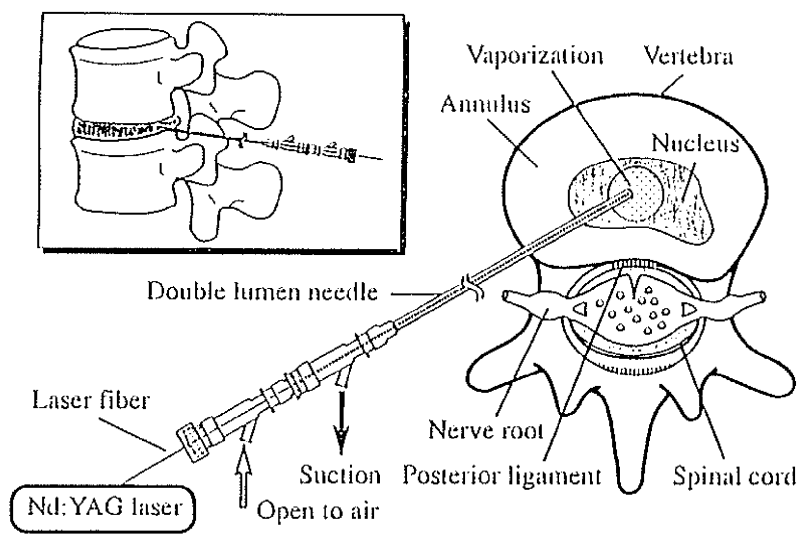

F i g - l P I L N 法：レーザー照射時

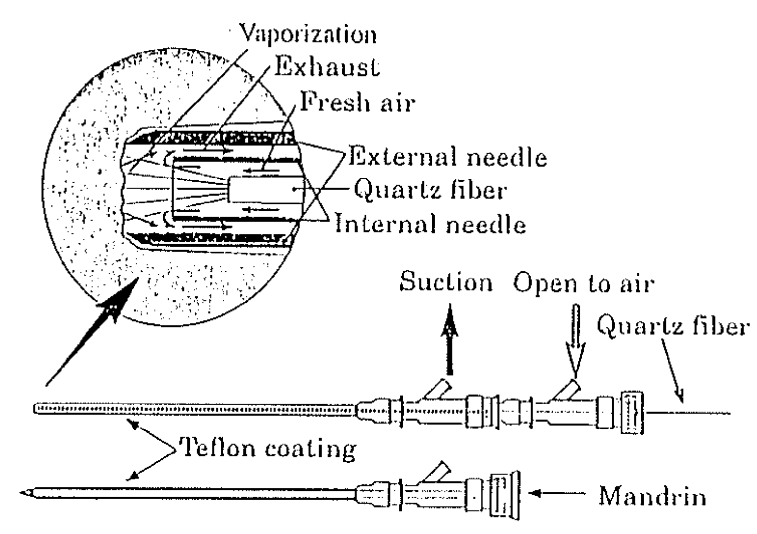

F i g-2 ダブルルーメンニードル 